\title{
EFFECTIVENESS OF PUBLIC-PRIVATE PARTNERSHIP IN THE MANAGEMENT OF TECHNICAL AND VOCATIONAL EDUCATION AND TRAINING
}

\author{
James Edomwonyi Edokpolor, Adesuwa Imafidon \\ Benson Idahosa University, Nigeria
}

\begin{abstract}
The aim of this research was to determine the effectiveness of Public-Private Partnership (PPP) in the management of TVET programme in the $21^{\text {st }}$ century. The preferred method of inquiry was the survey research design. A total population of 44 lecturers from the Department of Vocational and Technical Education, University of Benin and Ambrose Alli University was used for the research. The instrument for data collection was a structured questionnaire, validated by two experts. The Cronbach alpha formula was used to determine the instrument reliability; which yielded the coefficient value of 0.87. 20 questionnaire items was administered to the respondents by the researchers. The mean, standard deviation and t-test statistical tools were used for the data analysis. The results of the research showed that PPP to a high extent can influence the optimization of financial resources, provision of qualified manpower, development of curricula and procurement of modern facilities. There was also no significant difference between the mean ratings of TVET lecturers in UNIBEN and AAU regarding the influence of PPP on the effective management of TVET programme in the $21^{\text {st }}$ century. This indicates that TVET lecturers in both institutions have the same perception regarding the influence of PPP on the management of TVET programme. Based on these findings, 4 recommendations were made in the research.
\end{abstract}

Keywords: inadequate resources, management, Public Private Partnership, TVET programme.

\section{Introduction}

In a contemporary era of continuous and transformational change, individuals are being challenged to accept greater responsibility for constructing their own careers (both in vocation and education) across lifespan so as to develop relevant skills and keep pace with the emerging technological breakthroughs, together with the forces of globalization. Within this context, Technical and Vocational Education and Training (TVET) is critical not just to preparing people for the world of work, but in preparing them for life, and this is why it is so important to make TVET accessible to all (United Nations Educational, Scientific and Cultural Organization, 2013).

Technical and Vocational Education and Training has been defined as any programme that encompasses:

all educational and instructional experiences be they formal or informal, preemployment or employment related, off-the-job or on-the-job that are designed to directly enhance the skills, knowledge, competencies and capabilities of individuals, required in undertaking gainful employment, and irrespective of whether these experiences are designed and provided by schools, ... or higher education institutes, by private training providers or employers in industry and commerce (Maglen, 1996). 
The United Nations Educational, Scientific and Cultural Organization (UNESCO) and the International Labour Organization (ILO) collaboratively defined TVET as:

... those aspects of educational process involving, in addition to general education, the study of technologies and related sciences, and the acquisition of practical skills, attitudes, understanding and knowledge relating to occupations in various sectors of economic and social life (UNESCO \& ILO, 2002).

$\mathrm{Gu}$, Gomes and Brizuela (2011) further contended that TVET is a special type of programme that emphasized the application of skills, knowledge and attitudes required for employment in a particular occupation or cluster of related occupations in any field of social and economic activity. The Federal Republic of Nigeria (FRN) (2004) captures the essence and aspiration of TVET to its recipients as a human resource development strategy that leads to the acquisition of practical and applied skills as well as basic scientific knowledge for useful living within the society. The broad goals of TVET as contained in the education policy document shall be to:

a. $\quad$ Provide trained manpower in applied sciences, technology and business particularly at craft, advanced craft and technological levels;

b. Provide the technical knowledge and the vocational skills necessary for agricultural, commercial and economic development; and

c. Give training and impart the necessary skills to individual who shall be selfreliant economically (FRN, 2004:30).

The broad goals highlighted above suggest that the future success of Nigerian youths, enterprises and communities increasingly depend on the existence and possession of transferable and renewable TVET skills. In view of this, it behooves on the Nigerian governments to ensure adequate provision of financial resources for the effective management of TVET programmes. Osuala (2008) described management as the process of achieving organizational goals through co-ordinated performance of five specific functions, namely: planning, organizing, staffing, directing, and controlling. Accordingly, management of TVET can be seen as the arrangement of human and material resources and using them systematically for the attainment of TVET goals in effective and efficient manner. It can also be viewed as the effective and efficient provision and utilization of financial and other resources for the attainment of pre-determined goals of TVET.

The increasing demand for proper management of TVET in the $21^{\text {st }}$ century implies the need for substantial and consistent allocation of resources. Unfortunately, inadequate provision of financial resources has been identified as the greatest problem facing the education sector in Nigeria (Nwadiani \& Omoike, 2006; Asiyai, 2015). It would be recalled that the UNESCO, cited in Dauda (2011) and Adewuyi and Okemakinde (2013) has mandated all developing countries (including Nigeria) to allocate at least $26 \%$ of their annual budget to education. However, the highest Nigeria has allocated in recent years is $12.56 \%$ in 2000 , $6.88 \%$ in $2001,11.56 \%$ in $2002,6.89 \%$ in $2004,8.56 \%$ in $2006,9.49 \%$ in $2007,7.74 \%$ in 2008 , $10.13 \%$ in 2011, $10.48 \%$ in 2012, 10.58 in 2013, and $12.30 \%$ in 2014 respectively (Central Bank of Nigeria Statistical Bulletin, cited in Ogungbenle \& Edogiawerie, 2016). According to Odekunle (2001), government claim to be incapable of providing the required funds for the effective running of school system. Akaranta (2014) further pointed out that the standard argument for the Nigerian governments not to be capable of providing the required funds 
for the smooth running of the education system is the competing demand from other sectors. The excessive financial involvement that cannot be covered by the budgetary allocation has made successive governments of Nigeria to review their involvement in financing the education system. Furthermore, successive governments have often claimed that they can no longer bear the full responsibility of financing the education sector, especially TVET because of its capital intensive nature (Adeyanju, Odekunle \& Osifila, 2007).

Ekpenyong and Edokpolor (2015) asserted that the inadequate funding of TVET has led to the inadequate provision of staff, workshops, laboratories and studios which has consequently affected the production of skilled and competent graduates. They further claimed that these set of graduates may not be gainfully employed after graduation, due to lack of skills and attributes required by the employers of labour, nor be able to pursue further studies due to lack of interests. Since inadequate funding has been identified as the major challenge of TVET programme in the $21^{\text {st }}$ century, it is imperative to develop an alternative approach to adequate funding of TVET. This would help in ensuring the supply-driven system to a system that would meet the demands of the nation's population and industries. One strategy that may help in addressing the problem of inadequate funding of TVET is the introduction of the Public-Private Partnership (PPP).

The importance of PPP appears to lie in its ability to improve the effective management of TVET programme, as it may help to achieve greater optimization of finance so that qualified staff, better facilities, and quality curriculum can be made available. Fennell (2007) posited that the argument for the introduction of PPP in the 1990 was to bring in the management practices of the private sector into the public sector thus improving competitiveness and efficiency. He added that the understanding was that PPP strategy would make public expenditure more effective and in some cases would attract financial investment from the private sector. It is also hoped that PPP will bring on board the training providers with relevant labour market expertise, resources and diversity of perspectives to skills development (National Board for Technical Education, 2014). Furthermore, Jackson (2009) has made it known that PPP is about exploring relationship with the other organization, group or sector owing to lack of resources, capabilities or competencies.

The goal of PPP is to exploit synergies in a joint use of resources and in the application of management knowledge, with optimal attainment of the goals of all parties involved, where these goals cannot be attained to a great extent without the other parties. Although, conceptually PPP can be defined as a long-term contract between a private party and government agency, for providing a public service, in which the private party bears significant risk and management responsibility (World Bank Institute, cited in Roehrich., Lewis \& George, 2014). In the UK, Her Majesty's Treasury (1998) defined PPP as an arrangement between two or more entities that enables them to do work cooperatively towards shared and compatible goals and in which there is some degree of shared responsibility, risk taking, joint resource investment and mutual benefit. PPP has also been seen as cooperation between public-private actors in which they jointly develop products and services and share risks, costs and resources which are connected with these products and services (Van Ham \& Koppenjan, cited in Hodge \& Greve, 2005). It is defined as a contractual arrangement between the public and private sector to achieve well-defined and shared objectives in a wellmanaged cost effective, efficient and sustainable manner (Oni \& Akinbinu, 2005; Odekunle \& Babalola, 2009). The Asian Development Bank (2008) defined PPP as a contractual 
arrangement between public and private sector through which expertise, assets and financial resources of each sector are allocated in a complementary manner, thereby sharing the risks and reward, which seeks to provide optimal service delivery and good value to citizens. The European Investment Bank (2004) defined PPP as a generic term for the relationships formed between the private and public bodies often with the aim of introducing private sector resources and expertise in order to help deliver public assets and services effectively. The Institute for Educational Planning (2010) viewed PPP as the mobilization of resources, competencies and commitments by public, business and civil society partners to contribute to expansion and quality of education. It further added, that a PPP is founded on principles of international rights, ethical principles and organization agreement underlying educational development and management; consultation with stakeholders; and on shared decisionmaking, risk, benefit, transparency, and accountability.

There are several crucial concepts in the above definitions of PPP. One major concept is 'resources'. In almost all the definitions, provision of resources in an explicit way is mentioned as one of the key aspects of PPP. In addition to this observation, Adewuyi and Okemakinde (2013) pointed out that PPP in Nigeria includes: loaned executive programmes, where corporate executives work in specialized areas such as administration, staff development or resource management; curriculum renewal programmes, where corporate executives work with educators to develop curricula so as to reflect private-sector technology, standards and practices; mentoring programmes, where professionals have a direct link with individual students; and donation of equipment to schools. They further added, that the private sector can also form a partnership with the public schools by providing classroom space, buildings or lands; furnishing or equipping existing classroom space; providing equipment; providing maintenance services and utilities; providing teaching programmes; managing schools/school districts; and negotiating management deals that include the provision of infrastructure or infrastructural facilities after a time period. In addition, Majumdar (2011) reiterated that most countries around the world have realized the need for industries to take an active involvement in the TVET programmes in order to help in evolving new teaching-learning materials that will keep in step with the latest developments in the international work arena. He further added that many authors have underlined the importance of industries working closely with the TVET institutions and other agencies, so that the students will have access to the latest technologies and equipment that are used on the shop floors and for the educators and trainers themselves to have some grounding on current industry practices. The discussions so far have helped to unlock the rationale behind the partnership between public and private sectors; that is to mobilize the private sector resources for the effective delivery of TVET.

\section{Statement of the Problem}

Technical and vocational education and training is regarded as one of the most important programmes of instruction aimed at equipping students with practical skills and basic scientific knowledge for useful living within the society, yet inadequate funding has been identified as major challenge of the programme. Inadequate funding of TVET programme has led to the inadequate provision of qualified manpower, the insufficient supply of infrastructural facilities and equipment and the use of outdated curriculum. Successive 
governments have often claimed to be incapable of providing the required funds for the smooth running of education in Nigeria, especially the TVET programme due to its capital intensive nature (Adeyanju, Odekunle \& Osifila, 2007). This situation has consequently affected the production of skilled and competent graduates useful for technological breakthroughs; employment generation; poverty alleviation and industrialization because successive governments do not appear to give TVET programme the required attention (Ekpenyong \& Edokpolor, 2015a). Based on this unpleasant situation, the authors of this paper decided to posit the following question: Is Public-Private Partnership (PPP) the best management practice for TVET programme in the 21 st century?

The major purpose of the study therefore was to find out if PPP can serve as the best management practice for TVET programme in the $21^{\text {st }}$ century. Specifically, the study intends:

1. To determine the extent to which PPP can influence the optimization of financial resources for effective delivery of TVET programme.

2. To determine the extent to which PPP can influence the provision of qualified manpower resources for effective delivery of TVET programme.

3. To determine the extent to which PPP can influence the procurement of material resources for effective delivery of TVET programme.

4. To determine the extent to which PPP can influence the development of curriculum for effective delivery of TVET programme.

\section{Methodology of Research}

\section{General Background of Research}

The design for this research was the exploratory study by employing a survey design. Survey design is a non-experimental quantitative research method (Mitchell \& Jolley, 2007) aimed at collecting data and describing it in a systematic manner, the characteristic features and facts about a population of study (Omorogiuwa, 2006; Ary, Jacobs, \& Razavieh, 2010). Therefore, survey design is suitable for this research because it is meant to collect and analyse data from few lecturers who represented the entire population. The total population comprised of 44 lecturers, 28 lecturers from the department of vocational and technical education, University of Benin, Benin City and 16 lecturers from the department of vocational and technical education, Ambrose Alli University, Ekpoma.

\section{Sample Selection}

There was no need to adopt any sampling technique, nor select any sample size for the study because the population was manageable for the research. As a result, the entire population was used in the research, which comprised of 44 vocational and technical education lecturers. 


\section{Instrument and Procedure}

The instrument for data collection was a structured questionnaire titled: "Questionnaire on the Effectiveness of PPP in Managing TVET Programme (QEPPPIMTVEP)". In order to determine the validity, the instrument was given to two experts, one from the department of vocational and technical education, and the other from measurement and evaluation, Faculty of Education, University of Benin. In order to also ensure the reliability, the instrument was administered to twenty (20) lecturers who were not part of the research. The data was analysed using the internal consistency method, by applying Cronbach alpha formula to determine the coefficient alpha value, which was 0.89 . The instrument was further administered to the respondents by the researchers. The questionnaire was retrieved as soon as they were completed.

\section{Data Analysis}

The mean, standard deviation and t-test statistics was used for the analysis of data. The mean was used to answer the research questions, while the t-test was used to test the hypothesis at .05 level of significant. The standard deviations were used to determine the extent to which the responses were clustered to or deviated from the mean responses. The decision rule was based on any calculate mean equal or greater than 2.50 is regarded as high extent, while any mean lesser than 2.50 is regarded as low extent. Furthermore, any standard deviation value between the range of .00 and .96 indicated that lecturer's responses are very close in terms of their agreement. The probability value (p) was used in taking the decisions regarding the hypothesis. If the p-value is less than or equal to 0.05 the null hypothesis is rejected, and if otherwise, the null hypothesis is retained.

\section{Results of Research}

The data collected from the respondents were analysed using the mean () and Standard Deviation (SD) and the results are presented in Tables 1 to 4 .

Table 1. Mean and standard deviation of effectiveness of PPP on the optimization of financial resources for TVET programme.

\begin{tabular}{|c|c|c|c|c|}
\hline \multirow[t]{2}{*}{$\mathbf{S} / \mathbf{N}$} & Item Statements & $\bar{x}$ & SD & Remarks \\
\hline & \multicolumn{4}{|l|}{ To what extent can PPP help: } \\
\hline 1. & $\begin{array}{l}\text { To create opportunity for the managers of TVET institutions to ac- } \\
\text { cess private sector funds }\end{array}$ & 3.77 & .56 & $\mathrm{HE}$ \\
\hline 2. & $\begin{array}{l}\text { To create opportunity for TVET managers to effectively/efficiently } \\
\text { utilize the funds allocated to TVET programme }\end{array}$ & 3.77 & .42 & $\mathrm{HE}$ \\
\hline 3. & $\begin{array}{l}\text { To create opportunity for TVET managers to be accountable with } \\
\text { any funds allocated to TVET programme }\end{array}$ & 3.77 & .42 & $\mathrm{HE}$ \\
\hline 4. & $\begin{array}{l}\text { To create opportunity for TVET managers to become transparent } \\
\text { with any funds allocated to TVET programme }\end{array}$ & 3.73 & .45 & $\mathrm{HE}$ \\
\hline
\end{tabular}


Table 1 shows the mean scores of the opinion of respondents on the extent to which PPP can influence the optimization of financial resources for effective delivery of TVET programme. 4 items had mean rating that range from $3.73-3.77$, which indicates that PPP can influence to a high extent the optimization of financial resources for effective delivery of TVET programme. However, the standard deviation which range from $.424-.565$, indicates that the responses of the TVET lecturers are very close to one another.

Table 2. Mean and standard deviation of effectiveness of PPP on the provision of qualified manpower for effective delivery of TVET programme.

\begin{tabular}{|c|c|c|c|c|}
\hline \multirow{2}{*}{$\mathbf{S} / \mathbf{N}$} & Item Statements & $\bar{x}$ & SD & Remarks \\
\hline & To what extent can PPP help: & & & \\
\hline 5. & $\begin{array}{l}\text { To ensure the availability of funds so as to adhere to the mini- } \\
\text { mum standard of staff recruitment in TVET programme }\end{array}$ & 3.61 & .57 & $\mathrm{HE}$ \\
\hline 6. & $\begin{array}{l}\text { To ensure the availability of funds in order to source for the } \\
\text { right-caliber of staff in TVET programme. }\end{array}$ & 3.70 & .46 & $\mathrm{HE}$ \\
\hline 7. & $\begin{array}{l}\text { To ensure the provision of funds for the development of staff } \\
\text { skills through training and retraining programmes }\end{array}$ & 3.75 & .43 & $\mathrm{HE}$ \\
\hline 8. & $\begin{array}{l}\text { To ensure the provision of financial resources or grants for } \\
\text { TVET lecturers so as to upgrade themselves academically. }\end{array}$ & 3.68 & .47 & $\mathrm{HE}$ \\
\hline
\end{tabular}

Table 2 shows the mean scores of the opinion of respondents on the extent to which PPP can influence the provision of qualified manpower for effective delivery of TVET programme. 4 items had mean rating that range from $3.61-3.75$, which indicates that PPP can influence to a very high extent the provision of qualified manpower for the effective delivery of TVET programme. However, the standard deviation which range from .438.579 , indicates that the responses of the TVET lecturers are very close to one another. 
Table 3. Mean and standard deviation of effectiveness of PPP on the procurement of physical facilities for effective delivery of TVET programme.

\begin{tabular}{|c|c|c|c|c|}
\hline \multirow[t]{2}{*}{$\mathbf{S} / \mathbf{N}$} & Item Statements & $\overline{\boldsymbol{x}}$ & SD & Remarks \\
\hline & \multicolumn{4}{|l|}{ To what extent can PPP help: } \\
\hline 9. & $\begin{array}{l}\text { To provide TVET managers the opportunity to erect befitting } \\
\text { building for effective delivery of TVET programme }\end{array}$ & 3.68 & .47 & $\mathrm{HE}$ \\
\hline 10. & $\begin{array}{l}\text { To provide TVET managers the opportunity to procure instruction- } \\
\text { al materials for effective teaching and learning of TVET courses. }\end{array}$ & 3.73 & .45 & $\mathrm{HE}$ \\
\hline 11. & $\begin{array}{l}\text { To provide functional workshops for effective teaching and learn- } \\
\text { ing of technical education programmes }\end{array}$ & 3.82 & .39 & $\mathrm{HE}$ \\
\hline 12. & $\begin{array}{l}\text { To provide functional computer studios for the effective teaching } \\
\text { and learning of business education programmes }\end{array}$ & 3.75 & .43 & $\mathrm{HE}$ \\
\hline 13. & $\begin{array}{l}\text { To provide entrepreneurial research centres for TVET programme } \\
\text { so that students can always think entrepreneurially. }\end{array}$ & 3.70 & .46 & $\mathrm{HE}$ \\
\hline 14. & $\begin{array}{l}\text { To provide lecturers and students the opportunity to easily access } \\
\text { new or innovative technologies in the workplace }\end{array}$ & 3.70 & .46 & $\mathrm{HE}$ \\
\hline 15. & $\begin{array}{l}\text { To provide quality maintenance for TVET infrastructural facilities } \\
\text { and equipment. }\end{array}$ & 3.70 & .46 & $\mathrm{HE}$ \\
\hline 16. & $\begin{array}{l}\text { To provide TVET managers the opportunity to equip their libraries } \\
\text { with study materials, including ICT gadgets. }\end{array}$ & 3.66 & .47 & $\mathrm{HE}$ \\
\hline
\end{tabular}

Table 3 shows the mean scores of the opinion of respondents on the extent to which PPP can influence the procurement of material resources for effective delivery of TVET programme. 8 items had mean rating that range from $3.66-3.82$, which indicates that PPP can influence to a very high extent the procurement of material resources for effective delivery of TVET programme. However, the standard deviation which range from $.438-$ .479 , indicates that the responses of the TVET lecturers are very close to one another.

Table 4. Mean and standard deviation of effectiveness of PPP on the development of curriculum for effective delivery of TVET programme.

\begin{tabular}{|c|c|c|c|c|}
\hline \multirow[t]{2}{*}{$\mathbf{S} / \mathbf{N}$} & Item Statements & $\bar{x}$ & SD & Remarks \\
\hline & To what extent can PPP help: & & & \\
\hline 17. & $\begin{array}{l}\text { To grant TVET managers the opportunity to partner with captains } \\
\text { of industries for curriculum development that would reflect pri- } \\
\text { vate sector technology, standards and practices. }\end{array}$ & 3.61 & .49 & $\mathrm{HE}$ \\
\hline 18. & $\begin{array}{l}\text { To grant TVET managers the opportunity to easily introduce new } \\
\text { or contemporary courses into TVET curriculum. }\end{array}$ & 3.66 & .47 & $\mathrm{HE}$ \\
\hline 19. & $\begin{array}{l}\text { To grant TVET managers the opportunity to easily integrate mod- } \\
\text { ules of entrepreneurship skills into TVET curriculum. }\end{array}$ & 3.73 & .45 & $\mathrm{HE}$ \\
\hline 20. & $\begin{array}{l}\text { To provide the lead for TVET curriculum to strike a balance be- } \\
\text { tween courses offered and what is obtainable in the workplace }\end{array}$ & 3.64 & .53 & $\mathrm{HE}$ \\
\hline
\end{tabular}


Table 4 shows the mean scores of the opinion of respondents on the extent to which PPP can influence the development of curriculum for the effective delivery of TVET programme. 4 items had mean rating that range from $3.61-3.73$, which indicates that PPP can influence to a very high extent the development of curriculum for effective delivery of TVET programme. However, the standard deviation which range from $.451-.532$, indicates that the responses of the TVET lecturers are very close to one another.

Research Hypothesis 1: There is no significant difference between the mean ratings of TVET lecturers in University of Benin and Ambrose Alli University on the effectiveness of PPP in the management of TVET programme in the $21^{\text {st }}$ century.

Table 5. t-test analysis of the difference between TVET lecturers in UNIBEN and AAU on the effectiveness of PPP on the management of TVET programme in the 21st century.

\begin{tabular}{|c|c|c|c|c|c|c|c|c|}
\hline \multirow[b]{2}{*}{ Variable } & \multirow[b]{2}{*}{ Categories } & \multirow[b]{2}{*}{$\mathbf{N}$} & \multicolumn{2}{|c|}{ Aggregate } & \multirow[b]{2}{*}{ df } & \multirow[b]{2}{*}{ t } & \multirow[b]{2}{*}{ p } & \multirow[b]{2}{*}{ Decision } \\
\hline & & & Mean & SD & & & & \\
\hline $\begin{array}{l}\text { Effectiveness of PPP } \\
\text { on the Management of }\end{array}$ & UNIBEN & 28 & 3.68 & .315 & 42 & .226 & .229 & NR \\
\hline & $\mathrm{AAU}$ & 16 & 3.76 & .144 & & & & \\
\hline
\end{tabular}

The results presented in table 5 show that aggregate mean ratings of TVET lecturers in UNIBEN and AAU regarding the extent to which PPP can serve as the best management practice for TVET programme in the $21^{\text {st }}$ century is 3.68 and 3.76 respectively. The corresponding standard deviation is .315 and .144. The table indicated that the t-value is .226 at df of 42 , while the p-value is .299. Testing at alpha level of 0.05 , the p-value is not significant, since the $\mathrm{p}$-value is greater than the alpha value $(0.05)$. Therefore, the null hypothesis is not rejected; hence there is no significant difference between the mean ratings of TVET lecturers in UNIBEN and AAU regarding the important role of PPP in the effective management of TVET in the 21 st century.

\section{Discussion}

The findings from research question one, which seeks to find out the extent to which PPP can influence the optimization of financial resources for effective delivery of TVET programme, indicates that 4 items revealed that PPP to a very high extent can influence the optimization of financial resources for effective delivery of TVET programme. This finding is in line with the assertion of Fennell (2007) who noted that PPP strategy would make public expenditure more effective and in some cases would attract the financial investment from the private sector.

The findings from research question two, which seeks to find out the extent to which PPP can influence the provision of qualified manpower for effective delivery of TVET programme, indicates that 4 questionnaire items revealed that PPP to a very high extent can influence the provision of qualified manpower for the effective delivery of 
TVET programme. This finding is in conformity with Adewuyi and Okemakinde (2013) who asserted that PPP in Nigeria includes loaned executive programmes, where corporate executives work in specialized areas such as administration, staff development or resource management. This finding is also in agreement with the NBTE (2014) stipulated that PPP will bring on board training providers with relevant labour market expertise, resources and diversity of perspectives to skills development.

The findings from research question three, which seeks to assess the extent to which PPP can influence the procurement of material resources for effective delivery of TVET programme, indicates that 8 items revealed that PPP to a very high extent can influence the procurement of material resources for the effective delivery of TVET programme. This finding concurs with the opinion of Majumdar (2011) who asserted that most countries around the world have realized the need for industries to take an active involvement in the TVET programmes in order to help in evolving new teaching-learning materials that will keep in step with the latest developments in the international work arena. He also argued that many authors have underlined the importance of industries working closely with the TVET institutions and other agencies so that the students will have access to the latest technologies and equipment that are used in the shop floors and for the educators and trainers themselves to have some grounding on current industry practices.

The findings from research question four, which seeks to find out the extent to which PPP can influence the development of curriculum for the effective delivery of TVET programme, indicates that 4 items revealed that PPP to a very high extent can influence the development of curriculum for the effective delivery of TVET programme. This finding is in agreement with the assertion of Adewuyi and Okemakinde (2013) who pointed out that PPP in Nigeria includes: curriculum renewal programmes, where corporate executives work with educators to develop the curricula so as to reflect private-sector technology, standards and practices. Majumdar (2011) also noted that a stronger PPP can foster development of TVET curriculum that will further help to close the gap between the skills required by industry and those that students acquire at the end of the TVET programmes thereby helping TVET to respond to the skills needed by the industry.

\section{Conclusions and Recommendations}

Today, people live in a society that is faced with uncertainty which means that people are faced with the challenge and responsibility of continuously acquiring new skills. For this to materialize, greater emphasis needs to be placed on effective implementation of technically and vocationally-oriented education and training programmes. However, TVET is a programme that requires the provision of sufficient amount financial resources for effective provision of qualified staff, development of curricula that would reflect private sector technology, standard and practices; and procurement of a wide-range of modern facilities that would assist students to learn both comfortably and successfully. Based on this nature, successive governments have often claimed to be incapable of providing the required funds for TVET sector; hence it needs to provide an alternative approach for the effective management of TVET programme. One of such strategic approaches is PPP. This study, therefore, provides an empirical findings to better understand how PPP can serve as the best management practice for TVET programme in this $21^{\text {st }}$ century. 
Based on the findings of the study, it was specifically recommended that:

1. Governments should endeavour to mobilize the private sector actors in order to meet the tasks of attracting the financial investment from the private sector into TVET programme, thus, making public expenditure more transparent and accountable.

2. Governments should endeavour to mobilize the private sector actors in order to meet the tasks of improving the effective provision of qualified manpower for the proper delivery of TVET programme.

3. Private industries should endeavour to take an active involvement in TVET programmes so as to evolve new teaching and learning materials that will help teachers and students to access the latest technologies and equipment in the international work arena and for educators themselves to have exposure on current industry practices.

4. Private industries should endeavour to work closely with TVET institutions in order for educators to partner with corporate executives for the tasks of developing and renewing the curriculum of TVET programme.

\section{References}

Adewuyi, J. O., \& Okemakinde, T. (2013). Higher education financing in Nigeria: Issues and trends. International Journal of Educational Administration and Policy Studies, 5 (7), 121-127.

Adeyanju, J. A., Adekunle, A. A \& Osifila, G. I. (2007). Financing technical and vocational education (TVE) in Nigeria: The public-private partnership (PPP) option. In J. B. Babalola, G. O. Akpan \& A. O. Ayeni (Eds.), Managing technical and vocational education in the era of globalization. National Association for Educational Administration and Planning (NAEAP). Lagos. Awemark Industrial Printers. 103-106.

Akaranta, O. (2014). Building and maintaining higher education ecosystem in the 21st century. Paper Presented at a Workshop Organized by the Centre for Higher Education Studies, University of Port Harcourt. Port Harcourt, Nigeria.

Ary, D., Jacobs, L. C., \& Sorensen, C. (2010). Introduction to research in education ( $8^{\text {th }}$ Ed.). United States: Wadsworth, Cengage Learning. Retrieved from www.modares.ac.ir/uploads/Agr.Oth. Lib.12.pdf.

Asian Development Bank (ADB) (2008). Public-private partnership handbook. Manila, Philippines. Asian Development Bank, 12-25. Retrieved from www.apec.org.au/docs/adb\%20public\%20 private $\% 20$ partnership $\% 20$ handbook.pdf.

Asiyai, R. I. (2015). Challenges of quality higher education in Nigeria in the 21 st century. International Journal of Educational Planning and Administration, 22 (1), 33-34. Retrieved from https:// www.ripublication.com/ijepa/ijepav3n2_07.pdf.

Dauda, R. S. (2011). Health as a component of human capital formation: Does it matter for the growth of the Nigerian economy? Canadian Social Science, 7 (4), 207-218. Retrieved from www. cscanada.net/index.php/css/article/download/j.css.1923669720110704.../1876.

Ekpenyong, L. E., \& Edokpolor, E. J. (2015a). Winning the war against unemployment and poverty in Nigeria: Is there a role for TVET-private sector partnership? The Nigerian Vocational Association Journal (NVAJ), 20 (1), 125 - 132.

European Investment Bank (EIB) (2004). Private sector finance initiative in schools. Retrieved from http://www.audit-commission.gov.uk/Products/NATIONALREPORT/D7701D4F-C1304BA6-B10D6D0644BDAA98/pfi_briefing.pdf. 
Federal Government of Nigeria (2004). National Policy on Education. (Revised). Lagos: NERDC, 29-35.

Fennell, S. (2007). Tilting at windmills: Public-private partnerships in Indian education today. Retrieved from http://www.educ.cam.ac.uk/recoup/WP5-SF_PPPs.pdf.

$\mathrm{Gu}$, C. C., Gomes, T., \& Brizuela, V. S. (2011). Technical and vocational education and training in support of strategic sustainable development. Thesis submitted for completion of Master of Strategic Leadership towards Sustainability, Blekinge Institute of Technology. Karlskrona, Sweden. Retrieved from https://www.diva-portal.org/smash/get/diva2:832727/ FULLTEXT01.pdf.

Her Majesty Treasury (1998). Partnerships for prosperity: The private finance initiative. London.

Hodge, G., \& Greve, C. (2005). The challenge of public-private partnerships: Learning from international experience. Cheltenham: Edward Elgar. Retrieved from www.elgaronline.com/ view/9781843765097.xml.

Institute for Educational Planning (2010). Harnessing the power of public-private partnerships: The role of hybrid financing strategies in sustainable development. Retrieved from http://www.iisd. org.pdf.

Jackson, S. (2009). Strategic management. London: Darling Kindersley.

Maglen, L. (1996). VET and the university. Inaugural professional lecture. Department of Vocational Education and Training, University of Melbourne.

Majumdar, S. (2011). Emerging challenges and trends in TVET in the Asian-Pacific Region. Sense Publishers. Retrieved from https://www.sensepublishers.com/.../353-emerging-challengesand-trends-in-tvet-in-th.

Mitchell, M. L., \& Jolley, J. M. (2007). Research design explained (6 $6^{\text {th }}$ Ed.). Belmont, CA: Thompson Wadsworth. Retrieved from www.steporebook.com/book/research-design-explained-6thedition-96693-pdf.html.

National Board for Technical Education (NBTE) (2014). Guidelines and procedures for the establishment of private technical and technological institutions in Nigeria. Programmes Department Plot 'B' Bida Road, P.M.B. 2239, Kaduna - Nigeria. Retrieved from www.nbte. gov.ng/downloads/Guidelines\%20and\%20Procedures.pdf.

Nwadiani, M., \& Omoike, D. (2006). Financing primary, secondary and tertiary education in Nigeria. In J. A. Aghenta \& E. O. Omoregie (Eds.), Fundamentals of educational management. Agbor, Delta State. Krisbec Publications.

Odekunle, K. S. (2001). Funding of university education under democratic rule in Nigeria. Proceedings of the $21^{\text {st }}$ General Assembly of SSAN Held at NISER, Ibadan.

Odekunle, K. S., \& Babalola, J. B. (2009). Impact of public private partnership on quality assurance management of higher education in Nigeria. East African Journal of Educational Research and Policy, 2 (4). Retrieved from www.http/citeseerx.ist.psu.edu/viewdoc/ download?doi=10.1.1.525.5742\&rep=rep1...pdf.

Ogungbenle, S. K., \& Edogiawerie, M. N. (2016). Budgetary allocation and development in Nigeria tertiary institutions. Igbinedion University Journal of Accounting, 2, 377-407. Retrieved from www.iuokada.edu.ng/journals/8FDCD7F46066C28.pdf.

Omorogiuwa, O. K. (2006). Research and applied statistics for the behavioural sciences: An introduction. Mindex Press, Benin City.

Oni, B., \& Akinbinu, A. (2005). Public private partnership in Nigeria: A multi-disciplinary approach. NISER, Ibadan.

Roehrich, J. K., Lewis, M. A., \& George, G. (2014). Are public-private partnerships: A healthy option? A systematic literature review. Social Science and Medicine, 113, 110-119. Retrieved from http://opus.bath.ac.uk/39287/1/SS_M_PPPs_Roehrich_Lewis_and_George_14.pdf. 
United Nations Educational, Scientific and Cultural Organization (UNESCO) (2013). Shanghai Update: Follow up on the UNESCO third international TVET congress, 1, Bonn: UNESCOUNEVOC. Retrieved from: http://www.unesco.org/new/fileadmin/MULTIMEDIA/HQ/ED/ pdf/shanghaiupdateJune2013.pdf.

United Nations Educational, Scientific and Cultural Organization (UNESCO) and International Labour Organization (ILO) (2002). Technical and Vocational Education and Training for the Twenty-first Century: UNESCO and ILO Recommendations (Paris and Geneva). Retrieved from: http://unesdoc.unesco.org/images/0012/001260/126050e.pdf.

Received 31 May 2017; accepted 28 June 2017

\begin{tabular}{l}
\hline James Edomwonyi Edokpolor \\
Assistant Lecturer, Department of Education, Faculty of Arts and Education, Benson Idahosa \\
University, P.M.B.1100, Benin City, Edo State, Nigeria. \\
E-mail: jedokpolor@biu.edu.ng \\
\hline Adesuwa Imafidon \\
Lecturer II, Department of Education, Faculty of Arts and Education, Benson Idahosa University, \\
P.M.B.1100, Benin City, Edo State, Nigeria. \\
E-mail: aimafidon@biu.edu.ng
\end{tabular}

